\title{
Missional postures and practices for South African Baptist churches
}

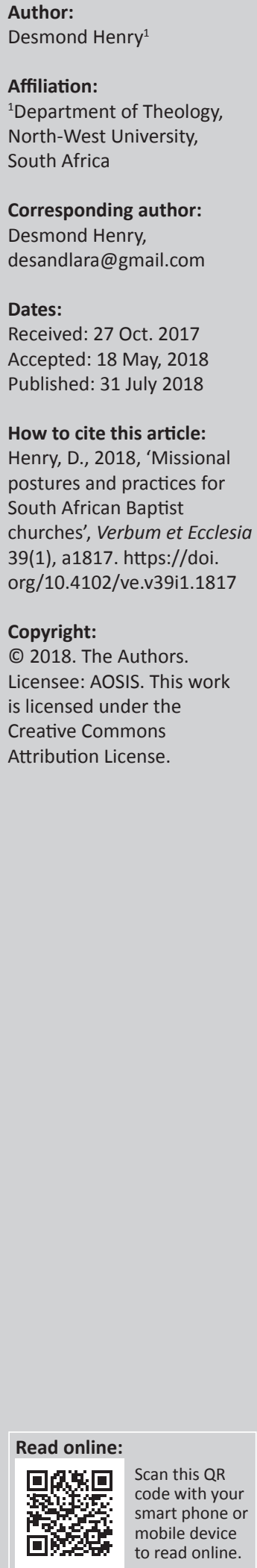

This article enumerates the importance of a missional posture in our Baptist cultural moment and details various issues related to the author's definition of the concept missio Dei. Moving to contextual practices among South African Baptists, the author deals with missional practices deployed in the Baptist context from a participant observer basis. Important principles for the effective implementation of those missional practices across the evangelical denominational divide can be drawn.

Intradisciplinary and/or interdisciplinary implications: This article seeks to challenge the modern conception of church as attractional and presents an alternative model that aligns with the recent missional conversations by highlighting five missional practices for congregations to implement for the common good. The fields of theology, missiology and ecclesiology are impacted by this study as it uses the author's contextual findings as participant observer.

\section{Cultural postures and the missio Dei}

There is no doubt that many churches remain increasingly ineffective within their ministry contexts as a result of a faulty conceptualisation of the missio Dei, their nature and role in society. Hastings (2012) reminds us that there exists within our culture today a cultural disconnection:

Cultural disconnection is the phenomenon that I am using to describe Christians and churches when they fail to relate the gospel relevantly because they do not adequately affirm and adapt to the positive aspects of human culture, and fail to distinguish between what is mere culture and what is the kerygmatic core of the gospel. (p. 38)

In addition, Peter Drucker, management guru, helpfully observes that 'people in any organisation are always attached to the obsolete - the things that should have worked but did not, the things that once were productive and are no longer' (Drucker 2010:66). In a similar vein, in his foreword to Woodward and White's (2016) publication of The Church as Movement, Allan Hirsch observes that many leaders seem to think that simply repeating and optimising the inherited habits of the church will eventually deliver paradigm-shifting results - this could not be further from the truth. We will establish that intention habits or missional postures and practices need to be discerningly cultivated. Mike Erre (2009) adds a helpful contribution to our discussion on the church and cultural postures:

Established churches are becoming increasingly ineffective because our past has not prepared us for ministry in the future. The discontinuity we have experienced because of these quantum leaps is comparable to the experience of the residents of East Berlin when the Berlin Wall came down. Nothing in their past prepared them for life without the Wall. Very little in our past has prepared us for ministry in today's world. (p. 19)

In many respects, many local Baptist churches have lost sight of their essential role as agents of God's mission. Furthermore, many churches in Africa have either capitulated to pop (Western) culture or traditional (African) culture (cf. Henry \& Malan 2017), being more concerned with cultural relevance, resulting in a watered-down doctrine, appearances and methodologies that appeal to the masses. Additionally, churches and pastors are increasingly becoming anathema to African society and are losing influence as a result of this faulty ministry hermeneutic. This is evident by the plethora of recent media activity around the church and pastors. Terry Tastard (2017) writes:

Since the end of apartheid, the number of these churches has increased greatly. Some are small, a few dozen adherents meeting under a tree. Some are not self-starts but affiliates of Nigerian or American ministries. The explosive growth of these churches raises questions, some unsettling, about the new South Africa, concerns exacerbated by media reports of exploitative pastors within these new congregations and of bizarre requests being made, for example: asking congregants to drink petrol or swallow a snake. (n.p.) 
Furthermore, in a popular Mail and Guardian article on 24 March 2016, Philip de Wet highlights the public view of faith outside the walls of religious institutions, where he states that in a country that is vastly religious and overwhelmingly Christian, political parties remain wary of the potential political energy that remains dammed up in churches, treading carefully when the state threatens to drag religion into the political realm by force. But otherwise they pay little heed to the supposed guardians of morality. Conrad Mbewe, a Reformed pastor in Zambia, in an interview with Bob Ditmer (2018) around the religious deception described above, says:

This teaching [prosperity preaching in Africa] has become a religious pyramid scam, with the so-called "men of God" reaping a fortune while their blind followers are getting poorer. Every day we have to deal with disillusioned individuals who have woken up when it's too late. This teaching is wreaking havoc in the lives of many Christians. (n.p)

More evidence and discussion could be included around this point (cf. De Wet 2017; Hansen 2011), yet one thing is clear: churches in South Africa have entered into a new season of public awareness and accountability, and how we respond collectively and as local churches will determine the extent to which we remain true to our quintessential mission - making disciples and transforming the world. The credibility and longevity of the church, in an antagonistic and increasingly secular world, is dependent upon the extent of our obedience to the missio Dei and what a right missional hermeneutic means for ministry in the real world.

On the opposite side of the spectrum, in the face of cultural change, many churches have retreated from the surrounding, somewhat antagonistic culture into ecclesial ghettos, where the world outside the parameters of the church is evil and is almost beyond the rule and reign of Christ. Many South African churches fall into these two polar-opposite approaches framed by Richard Niebuhr (cf. 2001) - the church being against culture (indifference) and then, on the other hand, the church being the church of culture (relevance paradigm). Is there not a better way? From a Baptist context the author previously published an article entitled 'Waves of Mission among South African Baptists' (Henry \& Niemandt 2014), where he concluded:

What is evident is that BUSA [Baptist Union of Southern Africa] is in an era of incredible opportunity or danger. It needs the recognition that any serious consideration of the magnitude of the task needs to be meted with the realisation that a new map is needed to guide BUSA towards fuller engagement within its constituency locally and regionally. (n.p.)

One thread of commonality that may assist Baptists in moving forward is the missional DNA entrenched in the founding of BUSA in 1877 and the formation of the South African Baptist Missionary Society in 1892. Preceding these significant events was the significant impact of the German Baptist settlers sent to South Africa under the able leadership of Carl Hugo Gutsche. The first wave of German settlers arrived in the early 1850s and among them were a number of
Baptists, one being a gentleman by the name of Carsten Langhein, who founded a Baptist church in Frankfurt in 1861. From this base, churches were planted in Berlin, Braunschweig and Hanover. At the German Baptist Union Assembly held at Hamburg in August 1867 and attended by Charles Haddon Spurgeon, an urgent appeal for trained pastors was made. It came from a body of believers, which had grown out of five Baptists among the 1857-1858 German immigrants to far-off South Africa (cf. Hudson-Reed 1977:22). The meeting in Hamburg appointed Oncken's assistant, Carl Hugo Gutsche, to the growing work in British Kaffraria (Christofides 2009:161). Roy and Hudson-Reed (2001:4) confirm that with Gutsche's arrival, an outstanding ministry had commenced that was to emulate that of Johan Oncken, who claimed of the membership of the early German Baptist churches that 'every member was a missionary'. As stated by HudsonReed (1977):

It is not surprising to find that Gutsche's first missionary meeting was held eight weeks after his arrival and within six months a missionary committee was operating in the church. As its first missionary, the church appointed not a minister but a teacher, Miss Harding. The church had started a school at Tshabo. (p. 22)

The Rev. Hugo Gutsche arrived in South Africa in 1867 and committed himself to working among the colonists and settlers of Kaffraria; thus, missionary zeal among the settlers was fanned into flame with the arrival of the German settlers, who were free from ecclesiastical restrictions (cf. Roy \& Hudson-Reed 2001). Rev. Gutsche was most successful in his ministry and was a gifted orator who drew crowds of people as he preached throughout the various settlements. 'Not only was he the people's pastor, but their legal advisor and doctor as well' (Batts n.d.:45). He established great works through the establishment of preaching stations at Keiskama, Stutterheim, Kingwilliamstown, Potsdam, Macleanstown, Queenstown and the Free State (Vrede). Batts (n.d.:46) said of Gutsche's work: 'he travelled, and the flame was kindled as he went along, and many believed and were baptised'. In 25 years Gutsche planted 25 churches throughout the Border area, which were all opened debt free because of his focus on planned giving (see Christofides 2009:161; cf. Roy \& HudsonReed 2001). Hudson-Reed (1970) also noted:

Although thwarted by internal quarrels and dissensions, and characterised by puritanical strictness which over-emphasized the unimportant, [the German Baptists] demonstrated a persevering faith and hope, and a loyalty to the church which made for growth and progress second to none in the annals of our history. (p. 54)

\section{Christofides (2009) confirms:}

By the time of the formation of the Baptist Union of South Africa in 1877, German-speaking Baptists slightly outnumbered English speaking Baptists, and there is still a strong German Baptist tradition in the Border region. (p. 161)

As demonstrated above, there exists an important missional thread in the history of the Baptist movement in South Africa that in their day would affirm much of the theological 
underpinning of the missio Dei renaissance evidenced in the 21st century post-colonial and post-modern world. Along with a plethora of authors, scholars and theologians, it is the author's firm belief that God is a missionary God, a fountain of sending love (cf. Bosch 2007), and that the fullness of God is involved in the sending character and capacity of the church, for which Christ died. This belief is summed up in the Latin phrase missio Dei (the mission of God) and has been popularised by theologians such as David Bosch, Lesslie Newbigin, Darrell Guder, Alan Roxburgh, David Dunbar, Steve Taylor, Alan Hirsch, Dwight Smith, Martin Robinson, Tim Keller and Ed Stetzer, among others. It seems to me that this term, along with the concept of being 'missional', is commonplace these days yet are not always used according to its true or fullest meaning. This in part led to the evangelical formulation of the Missional Manifesto led by framers of the likes of Ed Stetzer, Alan Hirsch, Tim Keller, Dan Kimball, Eric Mason, J.D. Grear, Craig Ott, Linda Bergquist, Philip Nation and Brad Andrews. The preamble to the Missional Manifesto (Stetzer et al. 2011) sets the tone theologically:

God is a sending God, a missionary God, who has called His people, the church, to be missionary agents of His love and glory. The concept missional epitomizes this idea. This manifesto seeks to serve the church by clarifying its calling and helping it theologically understand and practically live out God's mission in the world today. Although it is frequently stated 'God's church has a mission,' according to missional theology, a more accurate expression is 'God's mission has a church'. (Ephesians 3:7-13)

Despite the popularisation of this terminology these days, John Flett (2010) helpfully reminds us that:

the missio Dei is not something from which the Christian community can depart. Any other conception of the ground, motive and goal of mission apart from missio Dei's Trinitarian location risks investing authority in historical accident and human capacity. (p. 9)

The Missional Manifesto (Stetzer et al. 2011) reminds evangelicals that properly understanding the meaning of 'missional' begins with recognising God's missionary nature. The Father is the source of mission, the Son is the embodiment of that mission, and mission is done in the power of the Spirit. By nature, God is the 'sending one', who initiates the redemption of his whole creation. Jesus consistently spoke of himself as being 'sent' in John's gospel and subsequently commissioned his disciples for this same purpose (Jn 17:3, 8, $18,21,23,25)$. As the sent people of God, the church is the instrument of his mission (Jn 20:21). It seems that too many churches, Christian leaders and pastors have lost their way when it comes to this foundational truth, and we urgently need to recover the meaning and implications of the missio Dei for the common good. Gospel proclamation and demonstration flow from an all-consuming passion and commitment to the Gospel itself, and although being missional seems exciting it is not a quick-fix solution to a dying ministry; it remains to be God's heart for his bride and will require building a new construct through dependence on the Holy Spirit and discernment. Stetzer et al. (2011) indicate:

Missional represents a significant shift in the way we understand the church. As the people of a missionary God, we are entrusted to participate in the world the same way He does - by committing to be His ambassadors. Missional is the perspective to see people as God does and to engage in the activity of reaching them. The church on mission is the church as God intended. (n.p.)

\section{The church as missional}

In missiological conversations today there is an understanding that the local church is not the centre of the missio Dei-yet is central to it! Scot McKnight (2015) emphasises the fact that the local church is the hope of the world and an instrument of the missio Dei:

I hope you agree with me that the hope for the world is the local church, and that the heart of God's plan is found in creating a whole new society in a local church. (p. 102)

Jugens Hendriks, in his highly relevant work Studying Congregations in Africa, includes an important section on the local and global realities that exist today. He aptly quotes Andrew Walls (2001):

In considering the primacy of the church factor, it is worth remembering that the first effect of Christian expansion is not the production of saved or enlightened individuals, but of congregations ... it is doubtful whether the New Testament provides a single example of an individual convert, as 'saved individual,' left to plough his lonely furrow without a family or congregation. (p. 10)

There is a growing community of Christian leaders, pastors and scholars who are persuaded that mission is central to the life of the church - it is the life of the church! This is evidenced by the inclusion of the Missional Manifesto and reaffirms that reality that the church is sent into the world by God (missio $\mathrm{Dei}$ ) and therefore to be missional is a very fundamental statement about the church that should influence all other aspects and activities of the church. Van Engen (2011) reminds us to be mindful about using 'missional' terminologically:

Although many of us use it all the time, the phrase 'church and mission' may be misleading because the church is mission. To be missional belongs to the very essence of the church. It is therefore the local church and universal church as missional church. (p. 66)

Additionally, Hirsch (2006:63) insists, a proper understanding of 'missional' begins with recovering a missionary understanding of God. God, by his very nature, is a 'sent one', who takes the initiative to redeem his creation (as the Missional Manifesto affirms).

In summary, being missional is less about definition and more about mission. One cannot exist without the other, but both work hand in hand. BUSA churches tend to focus more on the definition aspect of mission and missions, which often prohibits action. Being missional relates to the intentional sending posture adopted by Christians living in post-1994 
South Africa, within the shadows of post-colonialism and post-modernism. McKnight (2015) reminds us of Paul's central theological idea:

This idea, that Paul's mission was a mixed assembly of differents, lies at the core of my beliefs about how the whole Bible works ... Are we willing to embrace the diversity of the church as the very thing God most wants? (p. 89)

The role of the church in mission today relates to her understanding of her essence and divine call, rights and responsibilities in the world, for the world and with the world. Being missional is more of a partnership in mission with the church acting in concert with individuals and communities through the power of the Holy Spirit to the glory of God. Missional, I believe, is contextual and takes the concerns of the Triune God for the world seriously and is willing, no matter what the cost, to engage others as they practise what Jesus taught - being salt and light (Henry 2015).

Bosch (2007:390), speaking primarily of the influence of postmodernism and African theologies, aptly states: 'We confess God to be a missionary God, a sending God, according to Bosch a "fountain of sending love"'. The Second Vatican Council decreed that mission is 'nothing else, nothing less, than the manifestation of God's plan, its epiphany and realisation in the world and in history' (specifically $\mathrm{Ad}$ Gentium 2, 9). Thus, God is believed to be a sending (and sent) God by nature and by plan who takes the initiative in dealing with the world. An evangelical perspective is found in the 1974 Lausanne Covenant, stating:

We affirm that Christ sends His redeemed people into the world as the Father sent Him, and that this calls for a similar deep and costly penetration of the world. We need to break out of our ecclesiastical ghettos and permeate non-Christian society. (cf. Lausanne Covenant, Article 6)

Furthermore, the 1989 Lausanne Manila Manifesto added a vital component:

Every Christian congregation is a local expression of the Body of Christ and has the same responsibilities ... We believe that the local church bears a primary responsibility for the spread of the Gospel. (cf. Lausanne Covenant, Article 8)

Speer, speaking in 1910 (quoted in Peters 1972), made this point:

The last command of Christ is not the deep and final ground of the church's missionary duty. That duty is authoritatively stated in the words of the great commission, and it is of infinite consequence to have had it so stated by our Lord Himself. But if these particular words had never been spoken by Him, or if, having been spoken, they had not been preserved, the missionary duty of the church would not be in the least affected. (p. 55)

The supreme arguments for missions are not found in any specific words. It is in the very being and character of God that the deepest ground of the missionary enterprise is to be found. We cannot think of God except in terms which necessitate the missionary idea ... the grounds are in the very being and thought of God. (p. 55)
This doctrine, known as missio Dei - the 'sending of God' - is causing many to redefine their understanding of the church in line with its intended Trinitarian orientation. Such inclination gives rise to the conviction that just as God is a missionary God, so the church must be a missionary church. Bliese (2006) says:

This is the fundamental meaning behind the four attributes of the Church confessed in the Apostles' Creed: one, holy, catholic (universal), and apostolic. Each of these marks of the Church points to the missional character of the people of God. (p. 238)

\section{Bosch (2007) states:}

The Church, as missio ecclesiae, is sent to represent God and God's mission in and over against the world, pointing to God ... in its mission, the Church witnesses to the fullness of the promise of God's reign and participates in the on-going struggle between that reign and the powers of darkness and evil. (p. 391)

'Missio Dei, then, articulates God's love for the world and God's initiative in saving it, which precedes and surpasses the Church' (Meiring 2008:792). Missio Dei reminds us that church identity and activity are unified. Flett (2010:28) reminds us that mission is not a secondary, optional and derivative thing that churches (or their delegates) do once they have the 'main thing down'. When we pull apart God and mission, Christian life and mission can get pulled apart, too. Sharing the gospel can end up being more like propaganda than the sharing of the gospel. Flemming (cf. 2015) helpfully shows that mission involves more than simply the church's cross-cultural missionary activity; 'it is anchored in the comprehensive mission of God' (2015:XVI).

This mission has been redefined biblically in the recent dialogue around the application of a missional hermeneutic by Wright (cf. 2006), who presents a substantial watershed for the conceptualisation of mission in the Old Testament. This was followed up by Flemming's (cf. 2015) interest in how to read scripture from a missional perspective by exploring both how the New Testament bears witness to the mission of God and how it energises the church to participate in that mission. Flemming (cf. 2015) develops the gaps represented by Wright's magnum opus, The Mission of God, with a comprehensive reframing of New Testament theology in the light of the missio Dei. Furthermore, Peters (1972:27) conjectures:

Missions is the progressive objectification of the eternal and benevolent purpose of God which roots in his very being and character and which embraces all ages, races and generations ... Missions is the historic effectuation of God's salvation ... missions is the practical realisation of the Holy Spirit operating in this world on behalf of the eternal purpose of God ... missionary theology is not an appendix to Biblical theology; it belongs at its very core. No doctrine of God, Christ or the Holy Spirit has been expounded completely according to the Bible until it has established the Triune God as the outgoing God of mission. (p. 27)

In addition to the conceptualisation of mission as Trinitarian, Hastings's (2012) theological reflection about the mission of 
God and the church represent an important contribution to the core foundational missional nexus in that he establishes the fact that 'the concept of the missional church is not a fad but is theologically foundational for the church, and more appropriate as an appellation than "deep" or "total"' (Hastings 2012: 35). Bevans and Schroeder (2011) argue:

The church comes to be as the church engages in mission ... to go into the world and be God's saving, healing, challenging presence ... mission precedes the church. Mission is first of all God's ... almost incredibly - as an act of grace - God shares that mission with women and men. Mission calls the church into being to serve God's purposes in the world. The church does not have a mission, but the mission has a church. (p. 15)

Important for our consideration, being missional relates to our understanding of the 'sending' posture of the Church and, as Guder (1998) argues, points to the unique call of the church to be in, with, for and against the world. Because we are the sent people of God, the church is the instrument of God's mission in the world. As things stand, many people see it the other way around. They believe mission is an instrument of the church, a means by which the church is grown. Although we frequently say 'the church has a mission', according to missional theology a more correct statement would be 'the mission has a church' (as is confirmed by Bevans \& Schroeder 2011, referred to above). Mission lies at the heart of the church's calling. The church does not (should not) exist to serve its own interests or to ensure survival and ecclesiastical continuity; rather, the church is called into being by the missio Dei; the Triune God's ongoing engagement with the world to reconcile (2 Cor 5: 17f), transform (Rm 12: 2, 3), conform and ultimately fulfil the original divine creative intent in it. God sent his Son into the world with a mission, the Holy Spirit is sent by the Father and Son with a distinct mission, and it follows that the church, baptised in the name of the Father, Son and Holy Spirit, is being sent into the world on a unique mission empowered and guided by the Holy Spirit. A statement from the Lausanne Covenant expresses the power of the Holy Spirit in world mission:

The Father sent his Spirit to bear witness to his Son; without his witness ours is futile. Conviction of sin, faith in Christ, new birth and Christian growth are all his work. Further, the Holy Spirit is a missionary spirit; thus evangelism should arise spontaneously from a Spirit-filled Church. A Church that is not a missionary Church is contradicting itself and quenching the Spirit. Worldwide evangelisation will become a realistic possibility only when the Spirit renews the Church in truth and wisdom, faith, holiness, love and power. We therefore call upon all Christians to pray for such a visitation of the sovereign Spirit of God that all his fruit may appear in all his people and that all his gifts may enrich the body of Christ. Only then will the whole Church become a fit instrument in his hands, that the whole earth may hear his voice. (Article 14)

The church exists to participate in the work of God as it worships and follows Jesus into the places in the world where God has sent it. The purpose of the church in mission is to point to the Kingdom of God and through the empowerment of the Holy Spirit ensure that the reign of God takes pre-eminence in the lives of men and women. James Smith (2016) reminds us that:

Jesus's command to follow him is a command to align our loves and longings with his - to want what God wants, to desire what God desires, to hunger and thirst after God and crave a world where he is all in all - a vision encapsulated by the shorthand 'the kingdom of God'. (p. 2)

Therefore, being missional does not presuppose a set of guidelines or rules to follow. Although popularised by some, there is no '10-step process' or magical formula to becoming missional - it is not another popular fad and claims no quickfix solution. Rather, being missional presupposes a journey of discernment and will require a fair amount of experimentation and risk (it tends to be counter-intuitive). Hastings (2012) is right when he states, in light of the misso Dei:

... the task of the church is not merely to wage war against prevailing culture but to offer a new, alternative culture, that of the church, which as a community and as its component persons become culture shapers in society. (p. 60)

The church's missional nature is rooted in the fact that being missional is biblical, historical, contextual, eschatological and practical (cf. Guder 1998). This encompasses McKnight's (2011) proposal for a gospel culture as opposed to a salvation culture. This is missional and truer to scripture and what Christ set out to accomplish. This means that being missional is rooted not in philosophy or ideological speculation but in biblical truth; it is rooted in the struggles of the worldwide church to remain true to its identity and calling throughout history; it is incarnational and universal, yet particular and local; it is contextual. Missional church is eschatological in that the church is moving towards a goal (telos [the end]), being God's new creation. The missional church is practical; it is not strictly theoretical, nor is it inapplicable; it affects people at grassroots level, which is one of the movement's greatest strengths.

\section{Christians as sent}

Charles Haddon Spurgeon, one of the greatest 19th century English preachers and theologians, is quoted saying: 'Every Christian is either a missionary or an imposter'. He pastored one of the first megachurches of the modern era, the Metropolitan Tabernacle, in London. Thousands of people came to faith under his ministry and it is estimated that he preached to upwards of 10 million people over the course of his life. Do you think that he meant that all Christians are to be missionaries and relocate to various parts of the world and serve in cross-cultural contexts, miles away from their home, family and friends? No, I am convinced that in Spurgeon's mind, the essence of what it means to be a Christian is that you live your life as a missionary, regardless of where you live. God calls us to a life of faithfulness and obedience wherever we are found.

Stetzer observes that modern Christians, particularly of the Western world, seem to trend toward one of two paths when they talk about God's mission. Either they will set off down a 
'sent-ness' path by emphasising the church as being sent and what it means to be missional, or they will go down a 'nations' path by emphasising the church as the one sending around the world. While these two paths are compatible, they seem too often to be followed in divergent directions. The reason for this is that the different parts of the missio Dei are often emphasised. Yet I think by exploring the commissions of Jesus, we get a better picture of God's mission. Additionally, reading the whole of scripture missionally, we are able to perceive the ways in which God has dealt with the nations and beckons his church to mission - we understand more clearly our missiology.

We are sent on mission. But what does that mean? It is important to note here that God has a mission and is on a mission. We find this in the biblical story. God is both sender and sent in Christ. God, the Father, is the source of mission. He sent his Son, who embodies God's mission and accomplishes it. God's mission is then extended and applied through the ministry of the Spirit, for it is the Spirit who calls, equips and empowers the people of God. The mission is therefore God's. He sends to accomplish his mission - the redemption of his whole creation. Jesus consistently spoke of himself as being 'sent' in John's gospel and subsequently commissioned his disciples for this same purpose (Jn 17:3, 8, $18,21,23,25)$. As the sent people of God, the church is the instrument of his mission (Jn 20:21). Missions flows from the mission of God.

A proper understanding of mission and of our responsibility toward its fulfilment as God's stewards and as agents of mission is foundational in any discussion on how churches and mission agencies in North America best collaborate and partner together. Thankfully, in recent years, through a focus on missiology and redefining of all things 'church', there is greater agreement, across the board, on the role and importance of the church and mission agencies in fulfilling the mission of Christ.

\section{Postures and practices for missional churches}

In today's increasingly complex cultural and social contexts globally, we have moved away from a Christendom mindset into post-Christendom realities, including post-modernism, post-colonialism and even post-Christian worldviews. Thus far we have dealt with the foundational aspects of the missio Dei and have laid out principles from this perspective that frame the missio ecclesiae. In this last section, I will address what this all means for regular believers, lay leaders and paid pastors within this era of seemingly discontinuous change, where traditional patterns of church life seem mundane and redundant. In many senses, being missional in these contexts is a breath of fresh air and can have deep and meaningful impact on a society averse to traditional models of Christian ministry. This aversion can be demonstrated in many instances globally because of the rise of the network society, aptly described by Manuel Castells (cf. 2000 in his voluminous work The Rise of the Network Society, which serves as a helpful watershed in thinking for missional movements and networks that have arisen both within and outside of traditional Christianity (and denominations). Castells (2000) reminds us that we live in a time of rapid change:

In the last quarter of the twentieth century, a technological revolution, centred around information, transformed the way we think, we produce, we consume, we trade, we manage, we communicate, we live, we die, we make war, and we make love. A dynamic, global economy has been constituted around the planet, linking up valuable people and activities from all over the world, while switching off from the networks of power and wealth, people and territories dubbed as irrelevant from the perspective of the dominant interests. (p. 1)

It is in this (new) world that the local church is called to minister God's grace (cf. McKnight 2015). Hendriks (2004) agrees with Castells's (2000) assertion that we live in a network age and adds that 'being a part of, and influenced by globalisation means that the era of continuous and chaotic change that characterises the Western World today ... also affects Africa' (2004:16).

\section{Missional practices for Baptist churches}

The undergirding methodology of this section of the article is upheld by a participant observer approach and draws from recent publications that presented the results of a mixedmethod approach that apply to this section on missional practices (for Baptists) specifically. Hendriks (2004) builds a strong case for what he terms 'congregational analysis that helps you to analyse your world'. For the purposes of this article's contextual focus, I wish to apply this, in a sense, to a denominational missional analysis as an application to a mixed-methods research methodology. Furthermore, 'the mixed-methods approach is expanding as a viable methodology in the social and human sciences, evidenced by a variety of books and journals reporting and promoting mixed-methods research' (Roberts 2010:144). More recently, Creswell and Clark (2011:1) observed that the mixed-methods approach has been called the 'third methodological movement'. It has also been named the 'third research paradigm' (Johnson \& Onwuegbuzie 2004:15) and 'a new star in the social science sky' (Mayring 2007:1). Creswell and Clark (2011:1f) argue that a mixed-methods approach is an intuitive way of doing research that is constantly being displayed through our everyday lives. A prime example of a mixed-methods approach is An Inconvenient Truth, the awardwinning documentary on global warming featuring the former US Vice-President and Nobel Prize winner Al Gore (Creswell \& Clark 2011:1). This example brings together both qualitative and quantitative data to narrate the story in a provocative and powerful manner.

So far, this article has presented a contextual theological argument that demonstrated a legitimate deficiency in a general conceptualisation of missionality among Baptists but an accompanying lack of missional praxis, increasingly so in 
the current era. There is an increasing need to espouse clear missional practices for Baptists (and broader evangelicals). A missional impulse can be identified as an impulse, habit and practice that emanates from a conceptual and biblical framework and leads toward missional flourishing. James Smith reminds us that we are not really motivated by abstract ideas or pushed by rules and duties. Instead some panoramic tableau of what looks like flourishing has an alluring power that attracts (2016). Missional practices are timely and timeless; they are deeply contextual, yet profoundly applicable in the human experience; they are attractive and lead to flourishing. Ultimately missional practices and impulses energise the missio Dei and lead neither to legalism or liberalism but to polycentric holistic mission. Missional practices are strategic and repetitive patterns of individual and community actions. These lead to encounters where God's activity and Christ's invitation to mission are discovered through the leading of the Holy Spirit. The following missional practices presented in application to the theory of this article are illustrative of the kind of dialogue that is needed. The missional practices below are derived from denominational analysis (cf. Hendriks 2004) and speak primarily to the cultural and missional moment evident among South African Baptists.

\section{Missional Practice 1: Vital spirituality evidenced by communal prayer}

One of the shortcomings of Christendom is religious arrogance and pride, where the church appears to have all the answers to society's ills and assumes that the masses are interested in their programmes, building and propaganda. A missional church's starting point is dependence upon God for discernment and guidance in cultural engagement and ministry. Missional churches have healthy prayer rhythms and are solely dependent on the Holy Spirit for their ministry methodology and not on an imported, somewhat pragmatic programme that worked in another context.

\section{Missional Practice 2: Discernment and consensus}

Too many churches have ceased listening to the culture around them and have an assumed pretence regarding the real needs, viewpoints and life issues of people. This is partly because of the loudness of the voices of congregation members insisting on being ministered to, and their needs being met. In a missional congregation, the needs of the community should receive at least equal attention as the needs of the congregation. Giving greater attention to the community will help churches to listen for the prompts of God's Spirit at work within the community in various places. I do not find it surprising that Jesus's last words as recorded in John's Revelation chapters 2-3 constantly mention 'he who has an ear, let him hear what the Spirit says to the churches'.

\section{Missional Practice 3: Deeply rooted fellowship}

The centrality of community to the proximity of the church leads to isolation and insulation in the long term. Christianity has always been and should always be a fellowship of believers, all-embracing, all-encompassing, all-encouraging, and part of this relates to the openness of believers to others at home in particular. In a Western, individualistic-oriented culture, we have lost some of the significance of food and fellowship as restoration in Christian community. I find it symbolic that one of the ordinances that the Lord chose for believers to remember him is something we enjoy in community and eat - bread and wine, symbolic of the body and blood of our Christ. A recovery of the simplicity, authenticity and generosity of Christian friendship and fellowship is a primary principle of missional Christianity.

\section{Missional Practice 4: Community understanding and service}

Contemporary Christianity has often compromised the message of the Gospel and means of salvation by restricting its proclamation as the role of paid professionals. There is certainly a valid place for the ministry of a paid pastor, yet in a missional context pastoral co-dependency is anathema; God has gifted the whole body for ministry (cf. Hirsch 2006). Paul reminds us that God has given some to be apostles, pastors, evangelists, shepherds and teachers for the edification of the body. An integral aspect of missional practice is the inclusive role of Christians in ministry - both congregant and clergy!

\section{Missional Practice 5: Grassroots evangelism}

BUSA started the second millennium with a renewed national and associational thrust on mission and evangelism from a denominational perspective. The focus here remained on associational church planting, reaching Muslims, inner city ministry and every church being a mission church. The effectiveness of this approach, however, is questionable and needs further establishment (cf. Henry 2015). Christofides (2009) includes this component in his research and indicates the following:

- There is a major shortfall in the rate of people who stay on in church and become fully participatory members.

- Not since 1997 have there been more people joining BUSA than people being baptised.

- The problem lies in the discipleship process within our churches - people are leaving BUSA churches without being grown and discipled in the Christian faith (cf. pp. 185-186).

\section{Missional Practice 6: Biblical discipleship}

Making disciples is a recurring theme of importance in scripture (see Mt 28:20; Mk 8:34-35; Mt 4:19; 11:29; 12:30, etc.), coupled with spiritual maturity evidenced through faithfulness and fruitfulness. BUSA churches have a varied approach to discipleship, but few manage to articulate and follow through with their process effectively. As stated in previous research (Henry 2015):

Perhaps the decline in attendance and participation by children, youth and young adults in our churches, and the declining 
numbers of BUSA students entering the Baptist Theological College (BTC) or the Cape Town Baptist Seminary (CTBS) is indicative of this discipleship malfunction. (n.p.)

\section{Conclusion}

This article has addressed missional postures and practices for Baptist churches in South Africa, interspersing global discussions and dialogue around being missional with local Baptist ecclesiology.

In summary, being missional is less about definition alone and more about missional activism. One cannot exist without the other, but both work hand in hand. In a previous article I stated (Henry 2015):

Despite the focus of BUSA's vision 2010 to double local church membership, double Baptist Union (BU) member churches, double the number of children and youth being reached, 300 churches with youth and young adult ministries, doubling the number of children's workers and teachers, 300 churches being 'mission involved', it seems that the exact opposite has been the net result. A similar trend regarding children and youth can be found within the young adult segment of BUSA. The only difference between children, youth and young adults is that the downward spiral in membership and participation for young adults started nationally from around 2008 (cf. Figure 5). This trend specifically is of great significance as it shows an evident weakness of BUSA churches to engage a generation of South Africans meaningfully with the gospel, disciple them adequately in the faith and deploy them responsibly in the mission of the church as it follows the mission $D e i$ in its teleological orientation. (n.p.)

The Baptist movement has always had an element of missional vitality that has deeply affected the trajectory of my life and ministry. When I was a child, I lived in an apartment in Florida. One day I was standing outside a supermarket where my mother was buying goods when a bus pulled up alongside me. It was a brightly coloured bus with loads of children singing and jeering. The bus stopped in front of me and a rather rotund man asked if I wanted to come to church. I asked my mother and she said I could go. If it were not for God's desire for me to be saved, the missional mindset of the local bus ministry of the Florida Baptist church and the heart of the bus driver to impact the next generation for the gospel, I may not be where I am today. The mission of God, which is the mission of the church, became my mission also (mission $\mathrm{Me}$ ).

I cannot see any other way - the church is quintessentially missional as God is love. A phrase evidentially propagated by Augustine of Hippo and popularised by Karl Barth in 1947, ecclesia semper formada, ecclesia semper reformada (the church must always be forming and reforming), remains an important consideration today; Baptists should continually re-examine themselves in order to maintain the purity of doctrine and practice. This remains to be the call of God for the church today - let's not become the cul-de-sac on the Great Commission Highway but a bridge of mercy to those who need it most in South African society.

\section{Acknowledgements}

I thank my missiological mentors, Professors Nelus Niemandt and Ed Stetzer, for their leadership and friendship in the Gospel and my seminary, Baptist Theological College, and the Ridgecrest Family church, who are always an encouragement. Most of all I thank my wife and daughters, who sacrifice time with me in order for me to research and write. For Christ and his kingdom!

\section{Competing interests}

The author declares that he has no financial or personal relationships that may have inappropriately influenced him in writing this article.

\section{Funding information}

Funding for this study was provided by the Faculty of Theology, North-West University, Potchefstroom.

\section{References}

Batts, H.J. (n.d). The story of 100 years, 1820-1920 being the history of the Baptist church in South Africa, T. Maskew Miller, Cape Town.

Bevans, S.B. \& Schroeder, R.P., 2006, Constants in context: A theology of mission for today, Orbis Books, Maryknoll, NY.

Bliese, R., 2006, 'The mission matrix: Mapping out the complexities of a missional ecclesiology', Word and World 26(3), 237-248.

Bosch, D., 2007, Transforming mission, Orbis, Maryknoll, NY.

Castells, M., 2000, The rise of the network society, 2nd edn., Blackwell Publishers, Oxford.

Christofides, P., 2009, 'The rediscovery of the role of the laity in the mission of the church - with reference to the Baptist Union of Southern Africa (BUSA)', PhD thesis, Dept. of Science of Religion and Missiology, University of Pretoria.

Creswell, J.W. \& Clark, V.L.P., 2011, Designing and conducting mixed methods research, Sage, London.

De Wet, P., 2016, Why the church is a nonplayer politically, viewed 24 March 2016, from https://mg.co.za/article/2016-03-23-why-the-church-is-a-nonplayerpolitically

De Wet, P., 2017, Christians close to 'regulation by reputation' for pastors, viewed 06 June 2017, from https://mg.co.za/article/2017-06-06-00-christians-close-toregulation-by-reputation-for-pastors

Ditmer, B., 2018, Meet the man making money off Christianity in Africa, viewed 06 April 2018, from https://churchleaders.com/news/322838-christianity-in-africadaniel-obinim.html

Drucker, P., 2010, The five most important questions self assessment tool, Jossey-Bass, San Francisco, CA.

Erre, M., 2009, Death by Church, Harvest House Publishers, Eugene.

Flemming, D., 2015, Why mission? (Reframing New Testament Theology), Abingdon Press, Nashville, TN.

Flett, J.G., 2010, The witness of God, Eerdmans, Grand Rapids, MI.

Guder, D.L. (ed.), 1998, Missional church: A vision for the sending of the Church in North America, Eerdmans Publishing, Grand Rapids, MI.

Hansen, C., 2011, Beware of Nigerian Religious Junk! viewed from 08 July 2011 https://www.thegospelcoalition.org/article/beware-of-nigerian-religious-junk/

Hastings, R., 2012, Missional God, Missional Church, IVP Academic, Downers Grove, IL. Hendriks, J., 2004, Studying congregations in Africa, Lux Verbi, Wellington.

Henry, D. \& Niemandt, C.J.P, 2015, 'Baptist identity and mission in a rainbow nation: Distilling imperatives from mixed-methods research within the Baptist Union of Southern Africa (1994-2012)', HTS Teologiese Studies/Theological Studies 71(2), Art. \#2026, 10 pages.

Henry, D. \& Malan, J., 2017, 'Considering the this-worldly religious focus of the African traditional worldview as found in South Africa', Verbum et Ecclesia [S.I.], 38(1), p. 12 pages. ISSN 2074-7705, viewed from https://verbumetecclesia org.za/index. php/ve/article/view/1742

Henry, D. \& Niemandt, C., 2014, 'Waves of mission amongst South African Baptists', Verbum et Ecclesia 35(1). https://doi.org/10.4102/ve.v35i1.843

Hirsch, A., 2006, The forgotten ways, Brazos Press, Grand Rapids, MI.

Hudson-Reed, 1970, By water and fire 1820-1877, South African Baptist Press, Pietermaritzburg. 
Hudson-Reed, 1977, 1877-1977 history of the Baptist Union of South Africa, S.A. Baptist Historical Society, Pietermaritzburg.

Johnson, R.B. \& Onwuegbuzie, A.J., 2004, 'Mixed methods research: A research paradigm whose time has come', Educational Researcher 33(7), 14-26. https:// doi.org/10.3102/0013189X033007014

Mayring, P., 2007, 'Introduction: Arguments for mixed methodologies', in P. Mayring, G.L. Huber \& I. Gurtler (eds.), Mixed methodology in psychological research, pp. 1-4, Sense Publishers, Rotterdam.

McKnight, S., 2011, The King Jesus Gospel, Zondervan, Grand Rapids, MI.

McKnight, S., 2015, A fellowship of differents, Zondervan, Grand Rapids, MI.

Meiring, P., 2008, 'Rethinking Missio Dei', Verbum et Ecclesia 29, 791-818. https://doi. org/10.4102/ve.v29i3.26

Niebuhr, R., 2001, Christ and culture, Harper Collins, San Francisco, CA.

Peters, G.W., 1972, A biblical theology of mission, Moody Press, Chicago, IL.
Roberts, C.M., 2010, The dissertation journey, Corwin Publishers, Thousand Oaks, CA. Roy, K. \& Hudson-Reed, S., 2001, No turning back, South African Baptist Historical Society, Pinelands.

Smith, J.K.A., 2016, You are what you love: The spiritual power of habit, Brazos Press, Grand Rapids, MI.

Stetzer, E. et al., 2011, The missional manifesto, viewed from 08 January 2018, http:// www.missionalmanifesto.net/index.html

Tastard, T., 2017, Christianity \& crisis in South Africa today, viewed 28 February 2017, from https://providencemag.com/2017/02/christianity-crisis-in-south-africatoday/

Van Engen, C., 2011, Paradigm shifts in Christian witness, Orbis, Maryknoll, NY.

Walls, A., 2001, The cross-cultural process in Christian History, Orbis, Maryknoll, NY.

Woodward, J.R. \& White, D., 2016, The church as movement, IVP, Downers Grove, IL. 